$\mathrm{Nr} 2(65), 2020$, s. 55-73

https://doi.org/10.12797/Politeja.17.2020.65.04

\author{
Małgorzata GOLIK \\ Akademia Ignatianum w Krakowie \\ malgosia.golik@gmail.com
}

\title{
DOJRZEWANIE DO WŁASNEGO GŁOSU, CZYLI REJWACH MIKOŁAJA GRYNBERGA
}

\section{ABSTRACT Maturing to One’s Own Voice, or 'Rejwach’ by Mikołaj Grynberg}

The early books by Mikołaj Grynberg containing conversations with survivors and their children allowed the writer to discover perspectives unknown to him before. With time these stories, combined with his own experiences, have become the basis for writing 'Rejwach'. In the article, while introducing the author's search for form, the author will show how the contemporary writing about the Holocaust has evolved. Grynberg, on the basis of testimonies he has heard, creates stories which many people affected by the Holocaust can identify with people from the first, second and even third generation of survivors. Although fictitious, they have a universal value.

Keywords: Mikołaj Grynberg, the Holocaust, post-memory, trauma, silence, fear

Słowa kluczowe: Mikołaj Grynberg, Holokaust, postpamięć, trauma, milczenie, lęk 
$\mathrm{M}$ ikołaj Grynberg jest fotografem i pisarzem, przedstawicielem tzw. drugiego pokolenia ocalałych, który w swoich książkach zajmuje się problematyką związaną z XX-wieczną historią polskich Żydów ${ }^{1}$. Poruszając niejednokrotnie bardzo trudne kwestie, przyjmuje wyróżniającą jego twórczość perspektywę dialogu i otwarcia na spotkanie $\mathrm{z}$ innymi - z ich opowieściami i przeżyciami. Jako syn ocalałych z Zagłady dorastał ze świadomością swojego pochodzenia i korzeni rodziny: Od 1966 roku, od chwili, gdy sie urodzitem, wiedziatem, że moja rodzina to polscy Żydzi, żytem w polskim domu, który byt żydowskim domem. Dostatem w prezencie i jedno, i drugie ${ }^{2}$.

W pierwszym, wydanym w 2012 roku tomie rozmów Ocaleni $z$ XX wieku. Po nas nikt już nie opowie, najwyżej ktoś przeczyta oddał głos dwudziestu pięciu ocalałym z Zagłady. W kolejnym, opublikowanym dwa lata później zbiorze Oskarżam Auschwitz. Opowieści rodzinne przeprowadził rozmowy z przedstawicielami drugiego pokolenia, czyli przede wszystkim swoimi rówieśnikami, dziećmi osób doświadczonych Holokaustem. W 2017 roku ukazała się książka Rejwach, będąca zbiorem trzydziestu jeden opowiadań. Rok później, w pięćdziesiątą rocznicę wydarzeń Marca 1968, pisarz wydał Księge Wyjścia zawierającą wywiady z Żydami z Izraela, Szwecji, Danii Stanów Zjednoczonych oraz Polski, których bezpośrednio dotknęły antysemickie zajścia. Podjął się w niej próby zrozumienia przyczyn, które skłoniły wówczas jego interlokutorów do opuszczenia kraju lub pozostania w nim. O swoim pisarstwie autor mówi następująco: Traktuje pisanie jako uchylanie okna do świata, który znam. I bardzo bym sobie życzyt, $\dot{z}$ eby inni, którzy żyja w światach, do których ja nie mam dostępu, te ż uchylali dla mnie to okno. Myślę, że w taki sposób zmienia się świat: zaczynamy rozumieć innych. I nie mam na myśli tylko kwestii narodowych ${ }^{3}$. Jednocześnie podkreśla, że nie mógłby napisać Rejwachu, gdyby nie czuł się pewnie w obu przypisanych mu rolach - Polaka i Żyda - i gdyby nie miał osobistego doświadczenia bycia Żydem w Polsce ${ }^{4}$.

W opowiadaniach składających się na Rejwach pisarz przedstawił przede wszystkim problemy dotyczące zarówno pierwszego, jak i drugiego pokolenia ocalałych. Anonimowymi, a przez to także uniwersalnymi bohaterami zbioru są ludzie z całej Polski, których łączy wspólne pochodzenie. Opowieści są próbą zrozumienia, dotarcia do sensu czy znaczenia (czyli okiełznania tytułowego rejwachu) poprzez literaturę i pokazania, jak kolejne pokolenia wciąż nie radzą sobie z przeszłością.

Autor przedstawia w zbiorze charakterystyczne dla drugiego pokolenia zagadnienia, stale obecne w domach rodzinnych ocalałych. Porusza takie aspekty, jak milczenie

Zdjęcia Mikołaja Grynberga prezentowane były niemal na całym świecie. Jest autorem albumów Dużo kobiet z 2009 roku oraz Auschwitz - co ja tu robię? z 2010 roku. Zob. A. Mazur, Mikotaj Grynberg, Culture.pl, 8 IV 2014, [online] http://culture.pl/pl/tworca/mikolaj-grynberg, 15 XII 2017.

2 P. Poznański, Destylat z bólu. Spotkanie z Mikotajem Grynbergiem, autorem książki „Rejwach”, Zupełnie Inna Opowieść, 28 IV 2017, [online] https://zupelnieinnaopowiesc.com/2017/04/28/destylat-z-boluspotkanie-z-mikolajem-grynbergiem-autorem-ksiazki-rejwach-zupelnie-inna-opowiesc/, 15 XII 2017.

3 E. Padol, Mikotaj Grynberg: dużo bólu i z wielu stron, Onet.pl, 19 IV 2017, [online] http://ksiazki. onet.pl/mikolaj-grynberg-duzo-bolu-i-z-wielu-stron-wywiad/cq0rk7, 10 XII 2017.

$4 \quad$ P. Poznański, Destylat z bólu... 
o Zagładzie, związane z nią lęk i traumę, a także kwestie tożsamości i pamięci. Dzieci ocalałych wciąż bowiem szukają sposobów, w jakie mogłyby mówić o przeszłości i jej dziedzictwie. Grynberg zwraca uwagę na kluczowe tematy, zestawia je ze sobą, szuka punktów wspólnych i różnic, uwypuklając jednocześnie najważniejsze kwestie, które pojawiają się niemal we wszystkich historiach. Wychodząc od typowych także dla pierwszego pokolenia problemów, nakreśla również zagadnienia charakterystyczne dla drugiego pokolenia, dostrzegając jednak - w odróżnieniu od wielu twórców drugopokoleniowych ${ }^{5}$ - ich uniwersalny i ponadosobisty charakter. Pod tym względem opowiadania Grynberga są dojrzałe i przemyślane, a przy tym tworzą spójny i obiektywny obraz drugiego pokolenia polskich Żydów.

\section{POTRZEBA PISANIA}

Od wieków podstawą żydowskiego trwania jest pamięć. Żydzi podtrzymują swoją tożsamość właśnie przez przypominanie zdarzeń, w których uczestniczyli ich przodkowie Od tysięcy lat wypełniają zawarty m.in. w Księdze Powtórzonego Prawa biblijny nakaz Zakhor (Zachor) - „Pamiętaj”. Mimo że dotyczy on każdego Żyda, odnosi się tak naprawdę do pamięci zbiorowej, a przez to konstruuje i buduje tożsamość grupy. Obecnie pamięć o Zagładzie jest jednym z głównych komponentów (jeśli nie kluczowym) zbiorowej pamięci Żydów na całym świecie ${ }^{7}$. Jak dowodził Yosef Hayim Yerushalmi: Czasownik „zachor”, w różnych formach koniugacyjnych występuje w Biblii ponad sto sześćdziesiąt razy, zazwyczaj w związku z podmiotami Izrael lub Bóg, jako że pamięć jest obowiąkiem ich obu. Dopetnieniem znaczenia tego czasownika jest jego przeciwieństwo - zapominanie. Tak jak Izraelowi nakazuje siępamiętać, tak i wymaga się odeń, by nie zapomniat ${ }^{8}$.

S. Majdosz, Pamięć i trauma dziedziczona w „Krajobrazie z dzieckiem” Romana Grena, „Oskarżam Auschwitz” Mikotaja Grynberga oraz „Pensjonacie” Piotra Pazińskiego, „Politeja” 2017, nr 47, s. 55-57. Dominującą narracją drugopokoleniową jest studium jednostkowego przypadku, w którym pisarz przedstawia zazwyczaj autobiograficzną historię będącą konfrontacją z pamięcią, traumą i przeszłością rodziców ocalałych z Zagłady. Są to m.in.: książki Ewy Kuryluk (Frascati. Apoteoza topografii, Goldi. Apoteoza zwierzaczkowatości), Magdaleny Tulli (Szum, Wtoskie szpilki), Agaty Tuszyńskiej (Rodzinna historia lęku), Bożeny Umińskiej-Keff (Utwór o Matce i Ojczyźnie). Zob. M. Cuber, Metonimie Zagtady: o polskiej prozie lat 1987-2012, Katowice 2013, s. 52-54.

6 H. Grynberg, Monolog polsko-żydowski, Wołowiec 2012, s. 62.

7 S. Ronen, Zakhor, [w:] Modi memorandi. Leksykon kultury pamięci, red. M. Saryusz-Wolska, R. Traba, współpr. J. Kalicka, Warszawa 2014, s. 544-545.

8 Y.H. Yerushalmi, Zachor. Żydowska historia i żydowska pamięć, przeł. M. Wójcik, Warszawa 2014, s. 39. Warto w tym kontekście przywołać Emila Fackenheima i jego propozycję dodanie do tradycyjnych sześciuset trzynastu przykazań zawartych w Torze kolejnego, sześćset czternastego nakazu, który wynika bezpośrednio z Auschwitz i nie pozwala, aby Hitler odnióst pośmiertne zwycięstwo. Z nakazem tym wiąże się, obok wiary w Boga, fizycznego przetrwania, także bezwarunkowa pamięć o Zagładzie, wbrew przeciwnościom losu, upływowi czasu i zamierzeniom jej inicjatorów. Nie tyle odsuwa na bok Przymierze i Prawo, ile wyróżnia właśnie Świadectwo. Zob. A. Molisak, Obecność Boga w historii - żydowska perspektywa po Auschwitz wedle Emila Fackenheima, [w:] Teraźniejszość i pamięćprzesztości. Rozumienie historii w literaturze polskiej XX i XXI wieku, red. H. Gosk, A. Zieniewicz, Warszawa 2006. 
Literatura dotycząca Holokaustu wyrasta także z biblijnego świadczenia o zbrodni. W kulturze żydowskiej nakaz ujawnienia niegodziwości pojawia się w Torze i Talmudzie. W Księdze Kapłańskiej napisano, iż kto mogąc zaświadczyć o przestępstwie, które widziat lub znat, nie uczyni tego, ciężko zgrzeszy (por. Kpł 5,1) ${ }^{9}$. W aspekcie tej tradycji świadkiem jest nie tylko naoczny widz, ale także ten, który ,jedynie” wie o popełnionym czynie. Zatem pisarz nie musi być już uczestnikiem czy świadkiem wydarzenia. Wystarczająca jest wiedza o zbrodni, aby zobowiązany był powiadomić o niej innych. Nie tyle więc naoczność, ile sama wiedza o przestępstwie czyni z tego, kto jąposiada, świadka. Wiedza ta jest zobowiazaniem. Status świadka bowiem implikuje obowiazek dania świadectwa - poinformowania innych o tym, co się wydarzyto. Ten obowiazek ma wymiar zarówno moralnej, jak i religijnejpowinności - stwierdza Jacek Leociak ${ }^{10}$. Zadaniem kolejnych generacji jest zatem wspominanie przeszłości oraz swoich najbliższych i zachowanie ich w pamięci, a więc nakaz świadczenia o ich losie oraz życiu.

Dziedzictwo Zagłady zostało przekazane kolejnym pokoleniom Żydów, a w szczególności drugiemu pokoleniu ocalałych. Tragiczną spuściznę powierzono ich pamięci - czy tego chcieli, czy nie. Dzieci ocalałych są pokoleniem, w którym otrzymana i przekazywana wiedza o wydarzeniach przeobraża się w historię lub opowieść o niej. Jest to również generacja, która stale zadaje pytania o przeszłość - poczynając od historii najbliższych, a kończąc na kwestiach dotyczących żydowskiej tożsamości i uniwersalnego znaczenia Zagłady. Eva Hoffman podkreśla, że jeśli chce się uniknąć spłycenia i trywializowania pamięci o Holokauście z powodu upływu czasu lub czyjejś ignorancji, a jednocześnie pragnie się zachować i przekazać choć część złożoności historii ocalałych, należy podjąć się jej indywidualnego zapisania i przekazania ${ }^{11}$.

\section{TRANSMISJA PAMIĘCI}

Przełomowa dla opisania narracji drugopokoleniowej stała się koncepcja postpamięci, którą zawdzięczamy Marianne Hirsch. Pojęcie to miało służyć opisowi sposobów, jakimi jednostki, które osobiście nie przeżyły konkretnych wydarzeń, mogą mimo to doświadczać ich posttraumatycznych symptomów i ukazywać je poprzez powtórzenie, utożsamienie czy mimesis ${ }^{12}$. Hirsch podkreśla, że połączenie się postpamięci ze swoim przedmiotem lub źródłem odbywa się przede wszystkim przez wkład wyobraźni i kreacji. Termin ten charakteryzuje więc doświadczenie tych, którzy dorastali zdominowani narracjami dotyczącymi wydarzeń poprzedzających ich narodziny. Ich własne

9 Pismo Święte Starego i Nowego Testamentu w przektadzie zjęzyków oryginalnych ze wstępem i komentarzami, red. A. Jankowski, L. Stachowiak, K. Romaniuk, przeł. W. Borowski i in., Poznań 2003.

10 J. Leociak, Tekst wobec zagtady (o relacjach z getta warszawskiego), Wrocław 1997, s. 119.

11 E. Hoffman, After Such Knowledge. A Meditation on the Aftermath of the Holocaust, London 2005, s. XI, XIV-XV.

12 A. Szczepan, Polski dyskurs posttraumatyczny. Literatura polska ostatnich lat wobec Holokaustu i tożsamości żydowskiej, [w:] Kultura po przejściach, osoby z przesztościa. Polski dyskurs postzależnościowy konteksty i perspektywy badawcze, red. R. Nycz, Kraków 2011, s. 241. 
wspomnienia są wypierane przez historie poprzedniej generacji, ukształtowane przez traumatyczne okoliczności, których nie można w pełni zrozumieć ani odtworzyć13.

Postpamięć ma w swój status wpisany charakter tożsamościowej strategii. Dotyczy bowiem nie tylko tego, co minione, ale obejmuje także teraźniejszość i przyszłość. Stanowiąc konsekwencję tragicznych wydarzeń, będących udziałem poprzedniego pokolenia, zawsze wiąże się z traumą, której doświadczenie jest po pierwsze prawdziwe, a po drugie możliwe do przekazania. W teorii postpamięci dostrzegalne jest także silne dążenie do podkreślenia jej ponadindywidualnego charakteru, gdyż mimo spersonalizowanych narracji oddziałuje ona na całą generacje $e^{14}$.

Drugie pokolenie dorasta otoczone obrazami i wspomnieniami z przeszłości, które wpływają na codzienne funkcjonowanie rodziny, oddziałując na społeczność, a nawet naród. Zawierają one w sobie ogromny ładunek emocji: strachu, rozpaczy i żalu, które z czasem zostają przejęte $\mathrm{i}$ włączone we własne wspomnienia przez pokolenie niedotknięte traumą bezpośrednio. Zostają one zapośredniczone, co prowadzi do zafałszowania przeszłości. W powstałych w ten sposób reprezentacjach rozmywa się wyraźna granica oddzielająca wspomnienia i pamięć własną od tych przyjętych w procesie transmisji15.

Hoffman stwierdza, że ślady pozostawione w psychice ocalałych z Zagłady to nie tyle myśli, ile blizny i rany. Dziedzictwo, które otrzymało drugie pokolenie, nie było więc przetworzoną, opracowaną przeszłością, lecz rozszczepionymi fragmentami cierpienia, żalu i straty, które w naszym współczesnym języku zaczęto nazywać traumą ${ }^{16}$. W czasie międzygeneracyjnego przekazu traumy przedstawiciel drugiego pokolenia, mimo panującego na temat przeszłości milczenia, wciąż wyczuwa smutek, zatroskanie i ciągłe napięcie rodzica. „Wchłaniając” niejako owe uczucia, jednocześnie styka się z deficytem innych. Wskutek odwrócenia procesu identyfikacji projekcyjnej dzieci stają się kontenerem na niemożliwe do pomieszczenia uczucia rodziców - żatoby i agresji ${ }^{17}$ - podsumowuje Sylwia Karolak.

Normalna historia może zostać przez nas wchtonięta, przyswojona, traumatyczna nie. W ten sposób traumatyczna przesztość - czy nasza prywatna, czy narodu lub kultury - istnieje w nas jako obce ciato, którego nie możemy zasymilować, ale też nie możemy się go pozbycic - pisze Ewa Domańska. Ponadto trauma i połączone z nią doświadczenie historii jest raną, która nigdy się nie zagoi. Opowieść, którą mieści w sobie trauma, stanowi zaledwie prawdę fragmentaryczną i nieciągłą. Jest ona bowiem subiektywna i zindywidualizowana, dlatego nie rości sobie też praw do bycia powszechnie respektowaną ${ }^{19}$.

13 M. Hirsch, Past Lives: Postmemories in Exile, „Poetics Today” 1996, vol. 17, nr 4, s. 659-686.

14 A. Szczepan, Polski dyskurs..., s. 242-243.

15 R. Więckowski, Postpamięć krytyczna w narracjach potomków ocalonych z Szoa (J. Dres, M. Grynberg, G. Rossenberg), „Politeja” 2017, nr 47, s. 64-65. Zob. też: M. Hirsch, The Generation of Postmemory. Writing and Visual Culture after the Holocaust, New York 2012.

16 E. Hoffman, After Such..., s. 34.

17 S. Karolak, Utwory o matkach i córkach. Kobiece narracje postmemorialne, „Politeja” 2015, nr 35, s. 179.

18 E. Domańska, Mikrohistorie. Spotkania w międzyświatach, Poznań 1999, s. 115.

19 S. Buryła, Prawda, reprezentacja, stosowność w literaturze Holokaustu, [w:] Prawda w literaturze. Studia, red. A. Tyszczyk, J. Borowski, I. Piekarski, Lublin 2009, s. 420. Na skutki, jakie niesie ze sobą transmisja pamięci ojców i matek, zwraca uwagę Joanna Tokarska-Bakir: Trauma dziedziczna jest o wiele 


\section{DRUGIE POKOLENIE OCALAŁYCH}

Potomkowie ocalałych z Zagłady nie chcą zapomnieć o przeszłości, która stała się udziałem ich bliskich. Szukają wszelkich nitek i strzępów łączących ich z rodzicami, za pomocą których mogą powiązać nie tylko ich historie, ale także połączyć je z własnym życiem. Drugie pokolenie chce o tych poszukiwaniach, swoich wątpliwościach i pytaniach mówić. Z tego też powodu powstała książka Oskarżam Auschwitz..., w której Grynberg prowadzi dialog z „braćmi i siostrami po Zagładzie”. Są to partnerskie rozmowy, w których mówią oni, jak doświadczenie rodziców wpływa na ich życie, emocje, wybory i losy ${ }^{20}$.

Dori Laub stwierdza, że powrót traumatycznych wydarzeń związany jest z kryzysem świadectwa. Słuchacz nigdy nie będzie bowiem w pełni gotowy na taką opowieść. Ma ona miejsce zawsze w nieodpowiednim czasie, kiedy jej odbiorca nie jest w stanie dostatecznie przygotować się na jej treść i emocje, jakie ze sobą niesie: „Świadkujący świadkowaniu świadka" stuchacz zostaje obarczony opowieścia o traumie niejako wbrew swojej woli i nie jest to nigdy tatwy do uniesienia „pakunek" ${ }^{\text {. }}$. Na kartach drugiej książki Grynberga wszyscy patrzą wstecz.

Według Grynberga jego bohaterów spaja fakt, że - tak jak pisarz - zostali wychowani przez ocalałych z Holokaustu. Czyli to, że są Żydami i mieli nie istnieć, gdyż ich rodziców miało nie być. Łączy ich to, jak zostali wychowani, a także atmosfera domów pozostająca w cieniu głębokiej żałoby. Co dzień konfrontowani byli, świadomie bądź częściej nieświadomie, z przetworzonym doświadczeniem Zagłady, która mogła być równie dobrze tożsama z pustką, jak i z nadmiarem. Pisarz zauważa jednak, że biorąc pod uwagę perspektywę ich rodziców, nie mogą oni narzekać na swój los, bo w tym kontekście brzmiałoby to jak bluźnierstwo. Przedstawiciele drugiego pokolenie czują, że mają drugą szansę, choć przecież sami nigdy nie stracili pierwszej. Jednocześnie towarzyszy im swoisty rodzaj nostalgii za światem i osobami, których nigdy nie mieli możliwości poznać. Nieczęsto mówią o nim innym, gdyż boją się, że mogliby zostać źle zrozumiani. Podobnie, jak ich rodzice, tematy te poruszają przede wszystkim w gronie podobnych im ludzi, we własnym środowisku, aby nie musieć przekonywać rozmówców do prawdziwości opowieści, które wydają się nieprawdopodobne i w które nie sposób uwierzyć2 ${ }^{2}$.

groźniejsza niż trauma pierwszego pokolenia, bo ktoś, kto ją niesie, doświadcza tylko jej skutków, nie mając dostępu do przyczyn. Zna on tylko pewna wersje przesztości i ze względu na więzy rodzinne ma ograniczone możliwości jej zrewidowania. J. Tokarska-Bakir, My z Jedwabnego, [w:] taż, Rzeczy mgliste. Eseje istudia, Sejny 2004, s. 208.

20 A. Grupińska, Wystuchiwanie Zagtady i rozmawianie o schedzie pozagtadowej, [w:] M. Grynberg, Oskarżam Auschwitz. Opowieści rodzinne, Wołowiec 2014, s. 7-8.

21 A. Mach, Świadkowie świadectw. Postpamięć zagtady w polskiej literaturze najnowszej, Warszawa-Toruń 2016, s. 365.

22 M. Grynberg, Oskarżam Auschwitz..., s. 17. 


\section{GRYNBERG - ROZMÓWCA}

Wśród powodów, które skłoniły Grynberga do pisania, było pragnienie zrozumienia tego, co się stało w czasie wojny. Chciał dotrzeć do sedna tego, czym było przeżycie w getcie czy obozie, i zobaczyć te miejsca oczami dwunastoletniej dziewczynki czy piętnastoletniego chłopca ${ }^{23}$. Zaczął spotykać się z ocalałymi, a jego rozmówcy decydowali się na spotkania z nim z potrzeby oczyszczającego wyznania i obowiązku dania świadectwa. Autor i rozmówcy zdawali sobie zapewne sprawę z tego, że z powodu upływu czasu przeprowadzenie tych rozmów jest konieczne, aby ich wspomnienia i historie nie zniknęly wraz z ich śmiercią. Grynberg chciał też przekazać przeszłość w inny sposób, niż robią to opisy historyczne, które jak sam podkreśla, nie przemawiają do niego ${ }^{24}$.

Grynberg wielokrotnie słuchał relacji swoich bliskich. Być może udało mu się w związku z tym wytworzyć mechanizm ochronny pozwalający mu żyć z opowieściami, których słucha ${ }^{25}$. Każda bowiem z poznanych historii wiązała się z bólem, cierpieniem i śmiercią, a obcowanie z nią na co dzień nie byłoby bez odpowiedniego zdystansowania się możliwe. Wielokrotnie pytano autora, czy po wydaniu książki czuje się lepiej. Odpowiadał, że nie i zapewne nie będzie się tak czuł. Podkreślał, że robi to, aby dzielić się poznanymi historiami z innymi, zwłaszcza że dzięki własnej sytuacji rodzinnej i wrażliwości potrafi wniknąć do tego świata. Grynberg podkreśla bowiem, że jeżeli chce się odczytywać Holokaust wprost, okaże się on niedostępny dla wszystkich. On sam lubi go rozszyfrowywać i udostępniać. Dodaje, że właśnie tym zajmuje się od wielu lat, nazywając to nawet swoim zadaniem do wykonania ${ }^{26}$. Aleksandra Szczepan zauważa, że w przypadku narracji posttraumatycznych działalność twórcy skoncentrowana jest wokół włączania porwanych historii, których jest słuchaczem, w obręb własnej opowieści, a tym samym własnego doświadczenia ${ }^{27}$. Nie inaczej jest w wypadku Grynberga.

W obu wspomnianych zbiorach pisarz posłużył się literaturą dokumentu osobistego. W wywiadach zachował indywidualny styl każdego z rozmówców i surową formę przekazu. Jako autor nie dodawał komentarzy, poza odautorskimi wtrąceniami, które miały na celu zwięzłe przedstawienie interlokutorów oraz nakreślenie okoliczności rozmów i towarzyszącego im nastroju. Zastosowany przez niego styl nieformalnego wywiadu umożliwia czytelnikowi zwrócenie uwagi na wszelkie pojawiające się w trakcie zwykłej rozmowy wahania, niedopowiedzenia czy chwile milczenia. Wszystkie one uzmysławiają emocjonalną atmosferę, w jakiej miały miejsce te zwierzenia, pokazując także niemożność wyartykułowania trudnych i bolesnych kwestii. Ascetyczność

23 M. Urbaniak, Mikotaj Grynberg: Uważam, by nieprzedawkować Auschwitz, Gazeta.pl, [online] http:// weekend.gazeta.pl/weekend/1,152121,21799862,mikolaj-grynberg-uwazam-by-nie-przedawkowacauschwitz.html, 11 XII 2017.

24 M. Grynberg, Ocaleni z XX wieku. Po nas nikt już nie opowie, najwyżej ktoś przeczyta, Warszawa 2012, s. 8.

25 Tenże, Oskarżam Auschwitz..., s. 286.

26 M. Urbaniak, Mikotaj Grynberg: Uważam, by nie przedawkować...

27 A. Szczepan, Polski dyskurs..., s. 250. 
zaprezentowanych tekstów powoduje z kolei, że to sam odbiorca musi dokonać interpretacji rozmowy, którą przedstawia czytelnikowi pisarz ${ }^{28}$.

\section{GRYNBERG - PISARZ}

Zbiór trzydziestu jeden opowiadań zawartych w tomie Rejwach jest efektem prac nad dwoma poprzednimi książkami, gdyż po ich lekturze zaczęli zgłaszać się do Grynberga ludzie pragnący opowiedzieć mu swoje historie. W czasie spotkań z nimi przypominały mu się także dziesiątki anegdot usłyszanych w przeszłości, które stały się materiałem lub inspiracją do napisania krótkich prozatorskich form. Wszystkie one mają swoje źródło w prawdziwych historiach - czy to z zasłyszanego zdania, krótkiego maila czy przeczytanej wcześniej książki. Grynberg pisał zatem fikcję na podstawie faktów, dzięki czemu powstały uniwersalne opowieści. Ludziom wystarczy nie przeszkadzać i nie usitować opowiadać o sobie, nie snuć wtasnej historii. Ja wtasna historię znam i niepytany jej nie opowiadam, lecz daję mówić innym. Bo ludzie maja wielka potrzebę dzielenia się historiami. A ja jestem ich ciekaw - stwierdza i zaraz dodaje: Krótka forma wynika z faktu, że chciatem podać te historie tak, by nie męczyć czytelnika, by raczej dać mu destylat z tego bólu 29 .

Inaczej niż przy pisaniu literatury dokumentu osobistego, w tworzeniu opowieści Grynberg czuł wolność, gdyż nie miał wobec swoich bohaterów żadnych zobowiązań. Sam mówi: Kiedy pytają mnie, czy „Rejwach” jest prawda czy fikcją, mówię, że wszystko, co w nim napisatem, jest prawdą, która wymyślitem ${ }^{30}$. Każdy bowiem tę samą historię opowiada na swój sposób. $Z$ tego powodu można nazwać owe historie prawdziwymi, mimo że nie są one odtworzone w skali 1:1, gdyż pisarz opowiada je własnymi słowami. Z wielu relacji autor tworzy jedną, własną, choć jednocześnie uniwersalną. Niektóre stanowia kompilacje wypowiedzi więcej niż jednej osoby, wszystkie zaś powstaty na skutek przefiltrowania przez wrażliwość pisarza faktycznych wypowiedzi. Dzięki temu pozostawiaja one po sobie jedynie mocny, zimny przekaz docierając do najgtębszych poktadów wrażliwości $i^{31}$ - pisze Dominika Pawlikowska.

Niemal każde z krótkich mających zaledwie dwie lub trzy strony, pozornie ascetycznych i noszących znamiona reportażu opowiadań ma własnego bohatera i jedno- lub dwuzdaniową pointę, w której autor dąży do aforystycznego podsumowania: Zawieszonego w próżni pytania, często wyrażonego nie wprost, na które odpowiedzieć musi także odbiorca, czyli ten, który „podstuchat" rozmowę $e^{32}$. W każdym z tekstów autor umiejętnie tworzy postać wyłącznie na podstawie języka i stylu wypowiedzi, jakim posługuje się

28 A. Kuchta, Zawtaszczone narracje. Obrazy postpamięci w zbiorze „Oskarżam Auschwitz. Opowieści rodzinne” Mikotaja Grynberga, „Konteksty Kultury” 2015, t. 12, z. 2, s. 252.

P. Poznański, Destylat z bólu...

30 M. Urbaniak, Mikotaj Grynberg: Uważam, by nie przedawkować...

31 D. Pawlikowska, Dziedziczenie pamięci: Mikotaj Grynberg, Rejwach, kreatywna.pl, 31 V 2017, [online] http://www.kreatywna.pl/kultura/ksiazki/dziedziczenie-pamieci-mikolaj-grynberg-rejwach/, 8 XII 2017. 
narrator. Słowa skomasowane do krótkiej formy stają się destylatem uczuć, a bohaterowie krwawia swoja historia ${ }^{33}$. W opowiadaniach do glosu dochodzą anonimowi polscy Żydzi. Każde ma bowiem innego bohatera - narratora, który postanowił opowiedzieć swoją historię „słuchaczowi”. W tekście występują sygnały tożsamości „słuchacza”, które wskazują na samego Grynberga. Inaczej jednak niż w poprzednich utworach pozostaje on niemy, nie prowadzi dialogu, nie dopytuje, tylko spisuje monologi narratorów, którzy rzadko oczekują od niego jakichś reakcjii ${ }^{34}$.

Grynberg podkreśla również, jak ważne dla niego jest dzielenie się poznanymi historiami. Czuje, że gdyby ich nie opowiadał udusitby się pod wpływem ich ciężaru lub wybucht z tego smutku. Przesiąknięty własną historią rodzinną i dramatycznymi opowieściami próbuje poprzez literaturę „strawić” tę wiedzę i towarzyszące jej uczucia. Dodaje: „Rejwach” to katalog moich strachów. Strachów, którymi bytem gotów siępodzielic ${ }^{35}$. Zwłaszcza że autor nie ukrywa inspiracji, które czerpał z własnego życia. Wątki autobiograficzne znajdują się m.in. w opowiadaniach Niemiec oraz Krzesto. W Krześle do Warszawy przyjeżdża ocalały, który doskonale pamięta miejsce, w którym się kiedyś ukrywał. Mimo że jest to wymyślona historia, ma ona prawdziwą podstawę w wydarzeniach z życia ojca Grynberga. Pisarz wspomina, że zabrał on kiedyś rodzinę na spacer po Marymoncie. W jego trakcie pokazał fundamenty domu, który w czasie wojny stanowił jego kryjówkę. Chodząc dookoła, szukał wejścia do piwnicy. Drogę podpowiedziała mu pamięć i konkretna, odmierzana niegdyś po ciemku liczba kroków. Przekazat nam wtedy historię, na która nie bytem gotowy. Dopiero po wielu latach zrozumiatem, gdzie wtedy bylismy ${ }^{36}$ - dodaje pisarz.

\section{MILCZENIE}

Jednym z najważniejszych zagadnień, z jakimi zmagają się bohaterowie Rejwachu jest obecne w rodzinach ocalałych milczenie. Bohaterka Eleganckiej torebki dorastała w domu, w którym nie mówiło się o przeszłości. Kolejne nalegania córki, aby matka pokazała jej rodzinny grób, kończyły się fiaskiem. Dopiero kiedy kobieta przeszła na emeryturę, postanowiła podzielić się z córką informacją o swojej tożsamości. Trauma Zagłady, następnie wydarzenia marca 1968 roku oraz lęk o bliskich nie pozwalały jej na to wcześniej. Na emeryturze, mając pewność, że nie ma już ryzyka utraty pracy i z powodu nalegań córki, „przyznała się” do swojej tożsamości. Milczenie okrywało niemal całą

33 A. Mach, Świadkowie świadectw..., s. 360. Zacytowany fragment nawiązuje do komiksu Arta Spiegelmana Maus. Opowieść ocalatego. 1: Mój ojciec krwawi historiq oraz Opowieść ocalatego. 2: I tu się zaczęty moje ktopoty (polskie wydania obydwu części komiksu pojawiły się w 2001 roku, a wydanie zbiorcze w $2010 \mathrm{roku})$.

34 A. Wójtowicz-Zając, Tajni Żydzi (Mikotaj Grynberg „Rejwach”), „Art Papier” 2017, nr 15-16, [online] http://www.artpapier.com/index.php?page=artykul\&wydanie=330\&artykul=6281, 10 XII 2017.

35 U. Rybicka, Fikcja okazata się prawda - rozmowa z Mikotajem Grynbergiem, „Chidusz” 2017, nr 38, [online] https://chidusz.com/mikolaj-grynberg-rejwach/, 12 XII 2017.

36 Tamże.Zob. M. Grynberg, Rejwach..., s. 99-101. 
rodzinną historię niezrozumiałym tabu, a wewnętrzny nakaz niemówienia o przeszłości uniemożliwiał nawiązanie jakichkolwiek relacji międzypokoleniowych opartych na pamięci ${ }^{37}$. Cisza na tematy najważniejsze, a tym samym związane z największym bólem obejmowała wszelkie dziedziny życia, powodując poczucie osamotnienia, wspierając nieufność i zaburzając komunikację.

Również bohaterka Konduktu zmagała się z obezwładniającą, niweczącą jakąkolwiek rozmowę o przeszłości ciszą, która wypełniała jej dom. Cisza, która była odpowiedzią na każde pytanie o historię rodziny, stała się powodem trudnych relacji matki z córką. Nurtowała ją bowiem przeszłość rodziny, próbowała się dowiedzieć, dlaczego ma tylko dwoje dziadków. Prosiła i szantażowała, gdyż rodzinna historia nie dawała jej spokoju, jednocześnie izolowała ją i skazywała na samotność. Zrozumiatam, że muszę szukać gdzie indziej. Bazy danych i archiwa państwowe staty sie mi blizsze od domu rodzinnego. Systematycznie je przeszukiwatam. Znalaztam tam swoich dziadków $w^{38}$ stwierdza bohaterka. Nadal nie pozwalało jej to zrozumieć, dlaczego rodzice tyle energii wkładali w ukrycie tych informacji ${ }^{39}$. Konfrontacja milczącej przez całe życie matki z wiedzą córki przyniosła tylko matczyną wściekłość. Nie umiała ona pokonać swojego strachu, zmienić pamięci wydarzeń i bez pogardy czy nienawiści mówić o rodzicach. Rodzinną drogę przez życie bohaterka opowiadania porównuje do tytułowego konduktu, który ruszył, gdy pierwszy raz zapytała matkę o bliskich. Szli w nim zawsze z całą rodziną - w milczeniu.

Bohaterki Grynberga same muszą zrekonstruować przeszłość rodziny, zbudować ją ze strzępków rozmów, żalów, krzyków i gestów. Nie tylko starają się ją odtworzyć, ale także zbudować własną pamięć i tożsamość. Odbywa się to jakby „między słowami”, sekrety bliskich osób są bowiem jednocześnie kluczem do ich własnych tajemnic. Mimo że wiedza na temat własnego pochodzenia może przynieść spokój, Grynberg w jednym z wywiadów podkreśla, że pokolenia rodziców i dziadków nie chcą mówić, bo często nie są w stanie. Niosą oni zbyt duży ciężar, który nie pozwala im zachowywać się inaczej. A zachęcanie czy zmuszanie ich do mówienia to przynoszenie bólu, a nie naprawianie świata. Kolejne pokolenia chcą jednak wiedzieć. Pisarz stwierdza: $W$ tej sprawie nie bẹdzie lepiej i musimy się nauczyć z tym żyć. Jeśli będziemy caty czas próbowali robić tysiace różnych rzeczy, żeby cośsię zmienito, to nie przeżyjemy naszej żatoby z tym zwiąanej. A to jest żatoba na wiele, wiele pokoleń. Po takich kataklizmach narody siępodnosza, ale trwa to dziesiatki lat. [...] O tym trzeba rozmawiać, ale z nadzieja na to, że kanat komunikacyjny jest drożny. Przesztości nie zreperujemy ${ }^{40}$.

Należy także brać pod uwagę fakt, że milczenie nie jest równoznaczne z niepamięcią. Po prostu pamięć jest tak straszna, związana z tak trudnymi przeżyciami, że ocalali nie chcą tam zaglądać. Nie chcą też, aby robili to ich najbliżsi, gdyż całe życie z wysiłkiem pracowali na rzecz zapomnienia. Psychiatra Krzysztof Szwajca podkreśla, że

\footnotetext{
A. Mach, Świadkowie świadectw..., s. 90.

M. Grynberg, Rejwach..., s. 47.

Tamże, s. 48.

E. Padol, Mikotaj Grynberg...
} 
nigdy nie przepracowali oni swych strat. Nie mieli możliwości użycia społecznie akceptowalnych rytuałów żałoby: nie mieli grobów, czasu ani emocjonalnych zasobów, aby opłakać śmierć dziesiątek bliskich i całego swego narodu ${ }^{41}$.

Jednak nie tylko milczenie może okazać się piętnem. Może nim być także rodzinna historia, o której bliscy dowiadują się po latach. Jednym ze stale powracających motywów jest sytuacja, w której odchodząc lub rozliczając się ze swoim życiem, ocalały lub świadek Zagłady wyjawia rodzinie swój sekret. Taką sytuację Grynberg przedstawia w historii zatytułowanej Niepotrzebne ktopoty. Jej bohater dowiaduje się od babci na łożu śmierci, że jest ona Żydówką i nie mogła odejść z tego świata, nie przekazując tej informacji najbliższym. Snując swoją historię stwierdza: Następnego dnia umarta nasza babcia nie-Żydówka cate życie. A kto zostat? Jej córka Żydówka i jej wnuki, Żydzi [...] $]^{42}$. Podkreśla jednocześnie, że choć wydaje się to niemożliwe, przekazała im ona nie tyle tożsamość, ile strach. Wiedza obciąża wszystkich, którzy ją posiadają, wzbudza lęk i bezradność, każe skonfrontować się z własną tożsamością i rodzinną przeszłością, a także na nowo spojrzeć na znane aspekty historii, którym dotychczas nie przypisywano większego znaczenia. Jest transmisją traumy i przede wszystkim strachu na kolejne pokolenia.

\section{LĘK}

Zarówno życiu w milczeniu, jak i w cieniu opowiadanych wciąż na nowo traumatycznych historii towarzyszy zawsze przekazywany przez bliskich lęk. Może on przybierać różne formy. W opowiadaniu Klasztor bohaterka, córka ocalałej, zostaje wysłana do klasztoru. Powodem umieszczenia tam kilkunastoletniej dziewczynki przez matkę jest lęk, jaki w sobie nosi od wojny, który przybrał na sile w trakcie prześladowań Żydów w 1968 roku. Obraźliwe wyzwiska sąsiada kazały jej, mimo braku zrozumienia tej decyzji przez dziecko, umieścić je w miejscu, które przed laty dało jej schronienie i najprawdopodobniej uratowało życie. W ciagu jednego dnia zostatam Żydówka i wierzaca katoliczkq $q^{43}$ - stwierdza bohaterka, która znalazła się w takiej sytuacji z powodu tkwiącego w rodzicach lęku.

O permanentnym uczuciu strachu, jaki wywołuje bycie Żydem w Polsce, opowiadają $S z a c h y$. Ich bohater obiecał matce na łożu śmierci, że nigdy nie powie nikomu o swoim pochodzeniu. Matka zarzekała się bowiem, że bez tego przyrzeczenia nie będzie mogła spokojnie umrzeć. Jej lęk, który wynikał z minionych wydarzeń, był tak silny, że przekazała go synowi. Mówi on: Chcężý́w Polsce, dlatego lepiej, żebym się nie ujawniat, dobrze jest, jak jest ${ }^{44}$. Grynberg tłumaczy decyzję swojego bohatera następująco: Mniej

41 K. Szwajca, Ocaleni z Holokaustu w oczach psychiatry, czyli o milczeniu i pamięci, [w:] Pamięć Shoah. Kulturowe reprezentacje i praktyki upamiętniania, red. T. Majewski, A. Zeidler-Janiszewska, Łódź 2009, s. 583.

42 M. Grynberg, Rejwach..., s. 9.

43 Tamże, s. 84.

44 Tamże, s. 67. 
bezpiecznie czuje się $w$ Polsce jako Żyd, więc to ukrywa, ale nie przed soba, tylko przed Polakami. Przed Polakami nie chce być Żydem, bo się boi. Poza tym obiecat swojej mamie, $\dot{z}$ enikt się nie dowie. A jego mama ukrywata, że jest Żydówka, ponieważ wiązato się z tym tyle ztych rzeczy, że postanowita ochronić kolejne pokolenia. Nie ona jedna ${ }^{45}$.

Innym rodzajem obecnego w potomkach ocalałych uczucia jest ich lęk o własnych rodziców. Wszelkie próby odzyskania siebie i życia własnym życiem, a nie matki czy ojca doświadczonego Zagładą, są nie tylko bardzo trudne, ale także pełne obaw o nieradzących sobie samodzielnie bliskich. Bohaterka Końca czasu stwierdza: Jeszcze troszkę rośniesz i już wiesz, że mama żyje tylko dla ciebie. Po jakimśczasie dociera do ciebie, że ty jesteś tylko dla mamy ${ }^{46}$. Panujące w domu milczenie i niemożność jakiejkolwiek rozmowy skłania bohaterkę do prób zerwania kontaktów z matką. Są one jednak nieudane - lęk o nią nie pozwala na odejście. Dzieci ocalałych czują się odpowiedzialne za rodziców. Pragną zrekompensować im przeżyte cierpienia, ciągle starają się być dla nich dobre. Izraelski psychiatra Haim Dasberg nazwal ten proces wzmożeniem odpowiedzialności międzypokoleniowej. Kiedy młodzi ludzie próbują opuścić dom, decydować o sobie, poczucie krzywdy i lęk rodziców wzmagają się. Z drugiej strony w ich dzieciach narasta także niepokój o nich i poczucie winy ${ }^{4}$. Kumulujący się lęk uniemożliwia wspólne funkcjonowanie, jednocześnie czyni również trudnymi jakiekolwiek próby usamodzielnienia się.

\section{TRAUMA}

Milczenie często bywa wynikiem traumy. W Tamtej historii Grynberg pokazał, jak zwykła dziecięca zabawa - ciągnięcie za sobą nogi przez chłopca - przywołała traumatyczną przeszłość, którą matka bohatera ukrywała do końca życia. Dopiero po jej śmierci okazało się, że osoba, którą uważał on za swoją mamę była w rzeczywistości jego babcią. Jego prawdziwa mama, cierpiąc na pewien rodzaj niepełnosprawności, z powodu którego ciągnęła za sobą nogę, została zabita przez Niemców. Już po śmierci babci i wyjaśnieniu tego, kim naprawdę była, przypomniała mu się historia z dzieciństwa. Bohater przywołuje sytuację, kiedy jako chłopiec wygłupiał się: Skakatem, robitem gtupie miny, ale mama jak zwykle byta niewzruszona. Zaczątem udawać, że mam chora noge i nie moge normalnie chodzić. Mama ztapata mnie za rękę i zawlokta do domu. Gdy mówię zawlokta, to doktadnie to mam na myśli. Ciagnęta mnie po ziemi, co jakiś czas nieudolnie próbując wzią́ mnie pod pachę. W domu dostatem lanie ${ }^{48}$.

Siłę traumatycznego, podporządkowującego sobie całe życie przeżycia pisarz pokazał także w opowiadaniu Klementyna. Jego bohaterka, mimo że upłynęło ponad siedemdziesiąt lat od końca wojny, nadal ukrywa swoją tożsamość przed najbliższymi. Od momentu, kiedy w 1940 roku rodzina oddała ją Polakom do ukrycia, żyje w kłamstwie.

\footnotetext{
E. Padol, Mikotaj Grynberg...

M. Grynberg, Rejwach..., s. 71.

47 M. Orwid, Przeżyć... I co dalej?, Kraków 2006, s. 285.

48 M. Grynberg, Rejwach..., s. 36-37.
} 
Zawsze chroniła się pod przybraną tożsamością. O swoim życiu mówi: Ukrywatam się, mimo że wojna się skończyta. Ukrywatam cata moja zamordowana rodzinę, która byta już tak dobrze schowana, że sama nie potrafitam jej odnaleźć. Oszukiwatam męża. Oszukiwatam dzieci. Oszukiwatam znajomych i koleżanki w pracy. Oszukiwatam caty świat! A wie pan po co? Po to, żeby żyćt9. Efekt silnego urazu nie kończy się bowiem z ustaniem zewnętrznego źródła, ale oddziałuje na dotkniętą nią osobę w sposób destrukcyjny przez całe życie.

O traumie nie do przepracowania, wynikającym z niej bólu, strachu i cierpieniu, dla którego jedynym rozwiązaniem jest perspektywa śmierci, opowiada z kolei Gorzka czekolada. Ojciec bohatera - na co dzień bardzo skryty i milczący - przekazuje synowi przerażającą historię z przeszłości. Gdy jego syn był w wieku, w jakim jest obecnie jego wnuk, chciał zabić swoje dziecko, bo sam nie miał wówczas sił żyć. $Z$ dalszej rozmowy wynika, że kiedy sam był w wieku wnuka jego matka popełniła samobójstwo, wcześniej próbując bezskutecznie pozbawić go życia. Jej niemożność funkcjonowania po śmierci reszty rodziny i trauma, jaka się z tym wiązała, stała się też udziałem jej cudem odratowanego dziecka. W jego słowach nie było nadziei: Gdyby mamie się udato, nie bytoby więcej cierpienia w tej rodzinie ${ }^{50}$.

Trauma usytuowana jest w konkretnym momencie życia dotkniętego nią człowieka, z tego powodu składa się ono dla niego ze straumatyzowanej przeszłości i bezbarwnej teraźniejszości. Dotknięta dramatycznymi przeżyciami, niepoddająca się zmianom część osobowości przestaje się rozwijać, co stanowi przeszkodę w próbach połączenia obu tych obszarów istnienia. Jednym ze skrajnych stanów jest życie w zapamiętanej przeszłości i odtwarzanie w teraźniejszości przeszłych doświadczeń ${ }^{51}$. $Z$ tego też powodu domy ocalałych były emocjonalnie bardzo trudne. Mimo ich pozornej normalności i zwyczajności, pełne były niejasnych, nieokreślonych napięć i tajemnic, które dotyczyły nie tylko historii rodzin, ale także aktualnych problemów i relacji ze światem.

\section{TOŻSAMOŚĆ}

W zbiorze pojawia się też często kwestia skomplikowanej żydowskiej tożsamości. Bohater Niemca dzięki brzmieniu swojego nazwiska miał możliwość ukrycia swojej narodowości przed innymi dziećmi. Stwierdza: Dzieci pytaty, dlaczego mam takie dziwne nazwisko, ale zanim znalaztem odpowiedź, jeden chtopak powiedziat, że pewnie niemieckie. Przytaknątem i zostatem Niemcem. Wieczór i noc miatem iście niemieckie. Dowiedziatem się, co im zrobiliśmy. Nie byli agresywni, ale byli zwycięzcami. Ja zaś bytem tym, który przegrat wojnę. I robiąc szybki bilans dotychczasowego doświadczenia związanego ze swoim pochodzeniem, tożsamością i sposobem, w jaki był przez ten pryzmat

49 Tamże, s. 57.

50 Tamże, s. 25.

51 B.A. van der Kolk, O. van der Hart, Natrętna przesztość: elastyczność pamięci i piętno traumy, [w:] Antologia studiów nad traumą, red. T. Łysak, przeł. T. Bilczewski i in., Kraków 2015, s. 171. 
postrzegany, dodaje: Ponieważ w moim krótkim życiu bytem już Żydem, który zabit Chrystusa, to pomyślatem, że może już lepiej być przegranym Niemcem ${ }^{52}$. Grynberg na tym przykładzie pokazuje atmosferę nieustannego badania i rozszyfrowywania rzeczywistości oraz zwraca uwagę, że neutralne nawet zachowania, z powodu doświadczeń rodziców, zmuszają do permanentnej ostrożności i czujności. W najlepszym wypadku generuje to jedynie lęk, w najgorszym każe całe życie ukrywać prawdę o tym, kim się jest.

O żydowskiej tożsamości, związanym z nią poczuciu obcości, a nawet odczuciu bycia gorszym Grynberg pisze także w tytułowym opowiadaniu Rejwach. Jego bohater stwierdza: Coś mi się dzisiaj wydaje, że tatwiejsze od bycia Żydem jest niebycie Żydem. Mam trochę lat i doświadczeń, chętnie panu opowiem caty ten rejwach ${ }^{53}$. I pokazuje różnice rzutujące na życie narodzonego dziecka w zależności od tego, czy urodził się u Stanisława i Jadwigi czy u Izaaka i Nehumy. Odwołując się do tożsamości młodego chłopca, pokazuje jego koleje losu i przeznaczenie, jakie jest i było pisane Żydom. Bohater dodaje: Zawsze czut, że tu jest jego dom, tutaj miat przyjaciót i miejsca, bez których nie wyobra$\dot{z}$ at sobie życia. Ale żydowski los dogonit Jurka. [...] Toczy żydowska wojnę. Na żydowskiej wojnie Żyd walczy z wtasnymi myślami i zawsze przegrywa. [...] Jurek już wie, że odziedziczyt bycie Żydem ${ }^{54}$. Podobnie o trudach związanych z własnym pochodzeniem pisze sam Grynberg, podkreślając, że nic złego nie zrobił. W tym kraju się urodził, podobnie jak jego ojciec oraz dziadkowie i ich przodkowie. Polskę z oczywistych względów uważa za swój dom, z którego niestety w 1968 roku niemal wyrzucono jego rodziców ${ }^{55}$.

Sytuacja nieco inaczej wygląda w przypadku bohatera opowieści Taglit, którego babcia wysłała na kolonie. Piętnastolatek początkowo nie rozumiał, dlaczego w grupie rozmawia się o Izraelu i w jakim celu udali się na żydowski cmentarz. Nie mogąc pojąć, co robi na koloniach dla Żydów, zadzwonił do babci, która powiedziała mu o jego pochodzeniu. Bohater podsumowuje rozmowę z nią następująco: Powiedziata, dlaczego przedtem nie mówita i dlaczego teraz już może mówić. Wiedziata, że moi rodzice tematu nie rusza, i czekata na dogodny moment. Sam nie wiem, co bym zrobit na jej miejscu, ale jestem jej wdzięczny, że się sprawa zajęta ${ }^{56}$. Nierzadko zdarza się zatem, że ciężar emocjonalny związany z żydowską tożsamością jest tak duży, że rodzicom lepszym rozwiązaniem wydaje się niewspominanie o niej.

\section{PAMIĘĆ}

Wielu twórców zarówno z pierwszego, jak i drugiego pokolenia ocalałych przywołuje w niezliczonych wariantach motyw fotografii. Niektórym z nich po przodkach pozostały tylko zdjęcia. Bywają one kluczem do przeszłości a czasami jedynym namacalnym

\footnotetext{
52 M. Grynberg, Rejwach..., s. 44.

53 Tamże, s. 15.

54 Tamże, s. 17.

55 E. Padol, Mikotaj Grynberg...

56 M. Grynberg, Rejwach..., s. 104.
} 
dowodem istnienia dziadków lub dalszych krewnych. Dla ocalałych fotografie rodzinne były cudem uratowanymi „śladami z popiołów”, materialnymi reliktami minionego świata. Często w opowieściach o Zagładzie przeglądanie fotografii z rodzinnego albumu jest jednym z rytuałów rozpoczynających pracę pamięci. Bywa jednak też tak, że fotografie nie otwierają dostępu do niej, ale odwrotnie, pokazują miejsca nieczytelne i niemożliwe do odtworzenia. Nie ułatwiają przybliżenia się do minionego, ale uzmysławiają niemożność tego aktu i istniejącą pustkę $e^{57}$. Odcięcie od przeszłości wydaje się całkowite i ostateczne, gdy po wojnie nie pozostały żadne fotografie. Nie istnieją wówczas „dowody rzeczowe” potwierdzające, że zabici w Zagładzie ludzie faktycznie kiedyś istnieli ${ }^{58}$.

Ciekawe w tym kontekście jest opowiadanie Eączenie rodzin, które nie tylko odwołuje się do zdjęć, ale porusza także kwestie konstruowania lub odtwarzania własnej tożsamości. Ojciec bohatera opowieści był fotografem, który stosując specjalną technikę wklejania na siebie zdjęć, łączył je w taki sposób, że z osobnych portretów matki, ojca i dziecka tworzył zdjęcia rodzinne, na których wyglądali, jakby wszyscy stali razem. Pewnego dnia chłopiec znajduje wiele odbitek wspólnego zdjęcia swojej rodziny, które zawsze wisiało w sypialni rodziców. Stwierdza: $W$ tej samej kopercie byty też trzy inne zdjęcia. Ja z jakimiś obcymi ludźmi i dwa portrety rodziców. Dopiero wtedy zauważytem, że ręce, które mnie trzymaja na naszym rodzinnym portrecie, nie są rękami rodziców. Przeciez gdyby to byty ich dtonie, toby sięprzenikaty z moimi, a te trzymaty mnie pewnym chwytem $^{59}$.

Kilka opowiadań dotyka także kwestii polskiej pamięci i reakcji samych Polaków na omawiane wcześniej kwestie. Postać przedstawiona w Arkadii to dobry Polak, którego działania - zakopywanie znalezionych żydowskich kości - podyktowane jest pragnieniem, aby dusze osiągnęły wreszcie spokój. Bohaterka Moich pięciu Żydów powiela z kolei rozpowszechnione stereotypy. Jest np. przekonana, że nie można ufać Żydom. Do takich wniosków doszła po tym, jak okazało się, że lubiana przez nią koleżanka z klasy „oszukiwała ją”, gdyż nie powiedziała jej o swoim pochodzeniu. Refleksja o tym, że w swoich wypowiedziach oskarżała niewinnych ludzi, przychodzi jednak za późno: Chciatabym przeprosić, ale już nie ma kogo ${ }^{60}$.

W końcu we Wspólnym dobru bohaterka przekonuje autora książek, Mikołaja, do spojrzenia na omawiane kwestie z jej perspektywy. Zachwyca się opisywanym przez niego zapomnianym żydowskim światem, ale jednocześnie pragnie pokazać mu „prawdziwy” obraz stosunków polsko-żydowskich, które jej zdaniem autor błędnie postrzega. Uważa, że jej sposób rozumienia konfliktów z przeszłości, umniejszania strachu, o którym pisze autor, i antysemickich zachowań, które nazywa chuligańskimi wybrykami, pomogą $\mathrm{mu}$ „poszerzyć perspektywę”.

57 A. Ubertowska, Literatura i pamięć o Zagtadzie: archiwa, ślady, krypty, [w:] Stosowność i forma. Jak opowiadać o Zagtadzie, red. M. Głowiński i in., Kraków 2005, s. 270-274.

58 A. Mach, Świadkowie świadectw..., s. 328.

59 M. Grynberg, Rejwach..., s. 117.

60 Tamże, s. 28. 
W przypadku wielu autorów, przedstawicieli drugiego pokolenia (choć sytuacje takie zdarzały się także pośród samych ocalałych), dojście do własnego głosu wymagało czasu, a ekspresja artystyczna, pisanie na temat przeszłości czy historii, przede wszystkim rodzinnej, nie przychodziło latwo ${ }^{61}$. W wypadku Grynberga droga prowadziła od fotografii, przez dwa tomy rozmów z ocalałymi i ich potomkami, do zbioru opowiadań. Pierwsze dwie książki pozwoliły pisarzowi zbliżyć się do tematu, a jednocześnie pokazać mu wiele nieznanych dotąd perspektyw. Wszystkie zasłyszane historie, połączone z własnymi doświadczeniami, stały się z czasem podstawą do napisania Rejwachu, w którym w formie zbioru opowieści przedstawił doświadczenia wspólne jego żydowskim rówieśnikom.

Ważność narracji drugiego pokolenia wynika z faktu, że pełni ono istotną funkcję w przejściu od pokolenia osobistego doświadczenia i żywej pamięci, do generacji polegającej na pamięci zbiorowej i historycznej rekonstrukcji ${ }^{62}$. Ważnym medium pracy pamięci jest narracja: Opowieść poprzez uporządkowanie materii faktów pomaga unaocznić i uchwycić ich znaczenie: jest to szczególnie istotne w sytuacji, gdy groza i nieludzkość faktów sprawia, że ich wartość informacyjna $i$ znaczenie wymyka się potocznej definicji rzeczywistości, i tym samym rozumieniu ${ }^{63}$ - dodaje Marek Zaleski.

W prozie Grynberga zawartych jest wiele problematycznych kwestii, z którymi zmaga się drugie pokolenie ocalałych. Jest tam więc dorastanie $w$ trudnych, pełnych tajemnic domach i skomplikowane relacje z rodzicami. Jest lęk o bliskich oraz nieufność wobec świata zewnętrznego, a także strach przed możliwością powtórzenia się Zagłady. Wszystkiemu zaś towarzyszy trauma - przekazywana z pokolenia na pokolenie, przekładająca się na wszystkie aspekty życia i nierozerwalnie związana z żydowskim pochodzeniem, które choć skrywane, w każdej chwili może zostać odkryte i stać się powodem śmierci najbliższych. Co ważne, w Rejwachu są też dostrzegalne aktywne działania przedstawicieli drugiego pokolenia, mające na celu odnalezienie swoich żydowskich korzeni, ugruntowanie własnej tożsamości oraz tym samym przełamanie traumy, która stała się ich udziałem. W tym wypadku sam akt pamiętania i zrozumienia sytuacji, w jakiej znaleźli się dziadkowie czy rodzice, oraz zaakceptowanie powodów nieprzystosowania pierwszego pokolenia do otaczającego go świata, stanowi rodzaj autoterapii, dzięki której transmisja traumy nie będzie musiała być udziałem kolejnego, trzeciego już pokolenia polskich Żydów. Także sam akt pisania, przelewania na papier własnych doświadczeń czy przeżyć innych, pozwala na zdystansowanie się do nich i ich przepracowanie. Jest to więc jednocześnie zarówno akt dania świadectwa, jak i oswojenie się

${ }^{61}$ Autorami „spóźnionych świadectw” wśród reprezentantów pierwszego pokolenia są m.in. Irit Amiel, Janina Bauman, Wilhelm Dichter, Michał Głowiński czy Roma Ligocka. Wśród późnych debiutów przedstawicieli drugiej generacji znajdują się książki Ewy Kuryluk, Magdaleny Tulli czy Agaty Tuszyńskiej, opublikowane niemal jednocześnie, na przestrzeni siedmiu lat.

62 T. Łysak, Powroty Evy Hoffman, „Res Publica Nowa” 2005, nr 5, s. 78.

63 M. Zaleski, Formy pamięci. O przedstawianiu przesztości w polskiej literaturze wspótczesnej, Warszawa 1996, s. 202. 
z bagażem osobistych doświadczeń. Przy czym w wypadku Grynberga forma przekazu, czyli zbiór uniwersalnych opowiadań, dodatkowo pieczętuje jego osobiste, trwające kilka lat rozliczenie się z traumą i przeszłością. Nie jest ono jednak ostateczne, gdyż już kolejny utwór tego autora, Księga wyjścia, przyniósł następną porcję rozważań na temat tożsamości polskich Żydów.

Ostatnie opowiadanie w tomie nosi tytuł Starorzecze. Jego narrator obecność Żydów w Polsce porównuje do rzeki. Według niego są oni zaledwie starorzeczem, przeminęli i istnieją zaledwie gdzieś z boku. Stwierdza: Chyba zdajesz sobie sprawę, że miejsce, w którym żyjesz, wysycha. Gdybyś urodzit się kilka pokoleń wcześniej, żytbyś w samym środku wartkiego nurtu. Nawet byśs sie nad tym nie zastanawiat i dodaje: Sa tacy ludzie na świecie, którzy uważaja, że nas tutaj nie ma. Dla nich jest nas tak mato, że aż nic. [...] My przecież wiemy, że żyjemy, że tutaj jesteśmy ${ }^{64}$. Skoro pojawiają się takie opowieści, jak Rejwach, skoro żyją ludzie, którzy je w sobie noszą, i ludzie, którzy chcą o nich czytać, oznacza to, że temat bynajmniej nie jest zamknięty ani wyczerpany. Zwłaszcza że istnieją tacy pisarze, jak Grynberg, którzy nie ustają w przypominania historii Zagłady i którzy podążyli za nakazem opowiadania i dania świadectwa. Ważne jest także to, że obok nich do swojego głosu i miejsca w polskiej literaturze dojrzewają już pisarze trzeciego, a nawet czwartego pokolenia ocalałych.

\section{BIBLIOGRAFIA}

Buryła S., Prawda, reprezentacja, stosowność w literaturze Holokaustu, [w:] Prawda w literaturze. Studia, red. A. Tyszczyk, J. Borowski, I. Piekarski, Lublin 2009.

Cuber M., Metonimie Zagtady: o polskiej prozie lat 1987-2012, Katowice 2013.

Domańska E., Mikrohistorie. Spotkania w międzyświatach, Poznań 1999.

Grynberg M., Ksiega wyjścia, Wołowiec 2018.

Grynberg H., Monologpolsko-żydowski, Wołowiec 2012.

Grynberg M., Ocaleni z XX wieku. Po nas nikt już nie opowie, najwyżej ktośprzeczyta, Warszawa 2012.

Grynberg M., Oskarżam Auschwitz. Opowieści rodzinne, Wołowiec 2014.

Grynberg M., Rejwach, Warszawa 2017.

Hirsch M., Family Frames. Photography, Narrative and Postmemory, Cambridge-London 2012. Hirsch M., Past Lives: Postmemories in Exile, „Poetics Today” 1996, vol. 17, nr 4, https://doi. org/10.2307/1773218.

Hirsch M., The Generation of Postmemory. Writing and Visual Culture after the Holocaust, New York 2012.

Hirsch M., Żatoba i postpamięć, przeł. K. Bojarska, [w:] Teoria wiedzy o przesztości na tle wspótczesnej humanistyki. Antologia, red. E. Domańska, Poznań 2011.

Hoffman E., After Such Knowledge. A Meditation on the Aftermath of the Holocaust, London 2005.

64 M. Grynberg, Rejwach..., s. 127-128. 
Karolak S., Utwory o matkach i córkach. Kobiece narracje postmemorialne, „Politeja” 2015, nr 35, https://doi.org/10.12797/Politeja.12.2015.35.13.

Kolk van der B.A., Hart van der O., Natrętna przesztość: elastyczność pamięci i piętno traumy, [w:] Antologia studiów nad trauma, red. T. Łysak, przeł. T. Bilczewski i in., Kraków 2015.

Kuchta A., Zawtaszczone narracje. Obrazy postpamięci w zbiorze „Oskarżam Auschwitz. Opowieści rodzinne” Mikotaja Grynberga, „Konteksty Kultury” 2015, t. 12, z. 2.

Leociak J., Tekst wobec zagtady (o relacjach z getta warszawskiego), Wrocław 1997.

Łysak T., Meandry ujawnienia - późne odkrycie tożsamości w „Rodzinnej historii lęku” Agaty Tuszyńskiej, [w:] Zagtada. Wspótczesne problemy rozumienia i przedstawiania, red. E. Domańska, P. Czapliński, Poznań 2009.

Łysak T., Powroty Evy Hoffman, „Res Publica Nowa” 2005, nr 5.

Mach A., Świadkowie świadectw. Postpamięć zagtady w polskiej literaturze najnowszej, Warszawa-Torun 2016.

Majdosz S., Pamięć i trauma dziedziczona w „Krajobrazie z dzieckiem” Romana Grena, „Oskarżam Auschwitz” Mikotaja Grynberga oraz „Pensjonacie” Piotra Pazińskiego, „Politeja” 2017, nr 47, https://doi.org/10.12797/Politeja.14.2017.47.04.

Molisak A., Obecność Boga w historii - żydowska perspektywa po Auschwitz wedle Emila Fackenheima, [w:] Teraźniejszość i pamięć przesztości. Rozumienie historii w literaturze polskiej XX i XXI wieku, red. H. Gosk, A. Zieniewicz, Warszawa 2006.

Orwid M., Przeżyć... I co dalej?, Kraków 2006.

Pismo Święte Starego i Nowego Testamentu w przektadzie z jezyków oryginalnych ze wstępem i komentarzami, red. A. Jankowski, L. Stachowiak, K. Romaniuk, przeł. W. Borowski i in., Poznań 2003.

Ronen S., Zakhor, [w:] Modi memorandi. Leksykon kultury pamięci, red. M. Saryusz-Wolska, R. Traba, współpr. J. Kalicka, Warszawa 2014.

Rottenberg A., Prosze bardzo, Warszawa 2009.

Spiegelman A., Maus. Opowieść ocalatego. 1: Mój ojciec krwawi historią, przeł. P. Bikont, Kraków 2001.

Spiegelman A., Maus. Opowieść ocalatego. 2: I tu się zaczęty moje ktopoty, przeł. P. Bikont, Kraków 2001.

Spiegelman A., Maus. Opowieść ocalatego. 1-2, przeł. P. Bikont, Kraków 2010.

Szczepan A., Polski dyskurs posttraumatyczny. Literatura polska ostatnich lat wobec Holokaustu i tożsamości żydowskiej, [w:] Kultura po przejściach, osoby zprzesztością. Polski dyskurs postzależnościowy - konteksty i perspektywy badawcze, red. R. Nycz, Kraków 2011.

Szwajca K., Ocaleni z Holokaustu w oczach psychiatry, czyli o milczeniu i pamięci, [w:] Pamięć Shoah. Kulturowe reprezentacje i praktyki upamiętniania, red. T. Majewski, A. Zeidler-Janiszewska, Łodź 2009.

Szwarcman-Czarnota B., W tańcuchu tradycji, [w:] Pamięć wędrówki, wędrówka pamięci, red. A. Lipowska-Teutsch, E. Ryłko, Kraków 2008.

Tokarska-Bakir J., My z Jedwabnego, [w:] taż, Rzeczy mgliste. Eseje i studia, Sejny 2004.

Ubertowska A., Literatura i pamięć o Zagtadzie: archiwa, ślady, krypty, [w:] Stosowność i forma. Jak opowiadać o Zagtadzie, red. M. Głowiński i in., Kraków 2005. 
Więckowski R., Postpamięć krytyczna w narracjach potomków ocalonych z Szoa (J. Dres, M. Grynberg, G. Rossenberg), „Politeja” 2017, nr 47, https://doi.org/10.12797/Politeja.14. 2017.47.05.

Yerushalmi Y.H., Zachor. Żydowska historia i żydowska pamięć, przeł. M. Wójcik, Warszawa 2014.

Zaleski M., Formy pamięci. O przedstawianiu przesztości w polskiej literaturze wspótczesnej, Warszawa 1996.

\section{Źródła internetowe}

Kuryluk E., Petrov M., Ewa Kuryluk: Jestem Australijka, Jewish.org.pl, 28 II 2011, [online] http://new.jewish.org.pl/aktualnosci/jestem-australijk-3963/, 7 XI 2017.

Mazur A., Mikotaj Grynberg, Culture.pl, 8 IV 2014 [online] http://culture.pl/pl/tworca/mikolaj-grynberg, 15 XII 2017.

Padoł E., Mikotaj Grynberg: dużo bólu i z wielu stron, Onet.pl, 19 IV 2017, [online] http:// ksiazki.onet.pl/mikolaj-grynberg-duzo-bolu-i-z-wielu-stron-wywiad/cq0rk7, 10 XII 2017.

Pawlikowska D., Dziedziczenie pamięci: Mikotaj Grynberg, Rejwach, kreatywna.pl, 31 V 2017, [online] http://www.kreatywna.pl/kultura/ksiazki/dziedziczenie-pamieci-mikolaj-grynberg-rejwach/, 8 XII 2017.

Poznański P., Destylat z bólu. Spotkanie z Mikotajem Grynbergiem, autorem ksiażki „Rejwach", Zupełnie Inna Opowieść, 28 IV 2017, [online] https://zupelnieinnaopowiesc. com/2017/04/28/destylat-z-bolu-spotkanie-z-mikolajem-grynbergiem-autorem-ksiazkirejwach-zupelnie-inna-opowiesc/, 15 XII 2017.

Rybicka U., Fikcja okazata się prawda - rozmowa z Mikotajem Grynbergiem, „Chidusz” 2017, nr 38, [online] https://chidusz.com/mikolaj-grynberg-rejwach/, 12 XII 2017.

Urbaniak M., Mikotaj Grynberg: Uważam, by nie przedawkować Auschwitz, Gazeta.pl, [online] http://weekend.gazeta.pl/weekend/1,152121,21799862,mikolaj-grynberg-uwazam-by-nie-przedawkowac-auschwitz.html, 11 XII 2017.

Wójtowicz-Zając A., Tajni Żydzi (Mikotaj Grynberg „Rejwach”), „Art Papier” 2017, nr 15-16, [online] http://www.artpapier.com/index.php?page $=$ artykul\&wydanie $=330 \&$ artykul $=$ 6281, 10 XII 2017.

Mgr Małgorzata GOLIK - absolwentka kulturoznawstwa, doktorantka na Wydziale Filozoficznym Akademii Ignatianum w Krakowie. Interesuje się literaturą współczesną, ze szczególnym uwzględnieniem zmagań twórców kultury z doświadczeniami wojny i totalitaryzmów. 